František Čermák

\title{
FRIENDS AND FRIENDSHIP IN PROVERBS
}

(based on a short version of Proverbs on Friends and Friendship to be published in Tavira, Portugal, by AIP-IAP)

\begin{abstract}
Friend is a familiar notion, existing probably in any language and culture. Yet it is far from clear what it exactly means, especially in human life. The many aspects it is related to offer many ways how to approach the topic. Out of these, by a random choice, one might select, as a starting point, old Roman There is no life without friendship, opening the scene of friends and friendship which seems so rich, and yet, knowing from our own personal experience and life, is in fact far from being rich. This contribution is mapping various aspects of friend-friendship relationship in various languages.
\end{abstract}

\section{KEYWORDS}

friend; friendship; proverbs

\section{Introduction}

Friend is a familiar notion in, probably, any language and culture. Yet it is far from clear what it exactly means, especially in human life. The word itself is one of the most frequent in any language (freq. 266 in Frequency Dictionary of American English, 2010, standing in close neighbourhood of father), though proverbs related to it are far from common in use, even though friends and friendship are valued high and considered to be pillars of the culture and everyday life.

It is obvious that to get at the essence of the friend-friendship phenomenon in proverbs linguistically one must have sufficient data to be able to arrive at any conclusions. Secondly, it will be inspiring to inspect the verbal image of proverbs in more than one language. Both requirements seem to be satisfied by the Routledge Dictionary of World Proverbs (STONE 2006) drawing on 130 languages and, in the 
author's selection, offering some 17 ooo proverbs. Of course, the selection must be subjective but, unfortunately, no firm objective data on the use and frequency of proverbs are available anywhere; thus, the choice of proverbs and languages is entirely his. This holds of the topic of friend/s in proverbs, too, which covers all of the proverbs the author has included. The total of proverbs found here is, surprisingly, high (about 200). Finally, it must added that the topic of friends-friendship being universal apparently, includes proverbs that repeat themselves in many languages and are thus overlapping.

Quite a few people give the topic of friendship more than a passing thought taking it as a very comon thing in life. Yet, a classic, who has stopped to give it some thought, the Roman Cicero (Marcus Tullius C., Laelius de Amicitia) wrote a few unforgettable observations already some 2000 years ago. They seem to be surprisingly modern even today.

The question, whether the longing for friendship is felt on account of weakness and want, so that by the giving and receiving of favours one may get from another and in turn repay what he is unable to procure of himself; or, although this mutual interchange is really inseparable from friendship, whether there is not another cause, older, more beautiful, and emanating more directly from Nature herself.

When the characters of friends are blameless, then there should be between them complete harmony of opinions and inclinations in everything without any exception; and, even if by some chance the wishes of a friend are not altogether honourable and require to be forwarded in matters which involve his life or reputation, we should turn aside from the straight path, provided, however, utter disgrace does not follow, for there are limits to the indulgence which can be allowed to friendship.

Let this law be established in friendship: neither ask dishonourable things, nor do them, if asked. Ask of friends only what is honourable; do for friends only what is honourable and without even waiting to be asked; let zeal be ever present, but hesitation absent; dare to give true advice with all frankness; in friendship let the influence of friends who are wise counsellors be paramount.

Two rules in friendship: first, let there be no feigning or hypocrisy; for it is more befitting a candid man to hate openly than to mask his real thoughts with a lying face; secondly, let him not only reject charges preferred by another, but also let him avoid even being suspicious and ever believing that his friend has done something wrong.

Some of his observations include the following

Friendship is nothing else than an accord in all things, human and divine, conjoined with mutual goodwill and affection. 
What is sweeter than to have someone with whom you may dare discuss anything as if you were communing with yourself?

Friendship cannot exist except among good men.

Friendship was given to us by nature as the handmaid of virtue, not as a comrade of vice.

For friendship excels relationship in this, that goodwill may be eliminated from relationship while from friendship it cannot.

Friendship adds a brighter radiance to prosperity and lessens the burden of adversity by dividing and sharing it.

For it is love (amor), from which the word "friendship" (amicitia) is derived, that leads to the establishing of goodwill.

You should love your friend after you have appraised him; you should not appraise him after you have begun to love him.

Complaisance gets us friends, plain speaking, hate.

To come back to the present time one might choose, as a starting point, some traditional proverbs offering a prototypical an general accepted truths. The gist of the topic seems to include ideas expressed by the following proverbs.

There is no life without friendship. (Roman)

A friend in need is a friend indeed. (English)

All are not friends who smile on you. (Dutch)

A man's oldest friend is his best. (Roman)

The image of friendship is truth. (Egyptian)

All of these are old. Two proverbs come to us from Roman times, one from the ancient Egypt pointing down, under the notion, at the substance of friendship. While the English proverb conveys perhaps the most acknowledged feature of proverbs related to a friendly help in need, the Dutch one brings in a trace of doubt warning the user that not everything is as it looks and one should look under the surface of friendship. Let us follow these and other strands related to the topic in some detail in a number of languages.

\section{Friends and Friendship}

\subsection{Friend: Identity and Qualities}

The notion of friend is highly personal for everyone, based on his/her experience but it is necessary to distinguish it from other common notions. It is evident that there is a lot of difference between friend and lover or friend and politician, even though some people may disagree. There is the feature of permanence and solidness which 
separates them. However, it is also necessary to distinguish friend from neighbour and brother, if we stick to proverbs.

\section{Friend or Brother}

The way brother is related to friend is to be seen in the following proverbs preferring friend to brother in some cases:

A brother may not be a friend, but a friend will always be a brother. (Poor Richard)

A friend by thee is better than a brother far off. (Irish)

while the real difference may not be so great, cf.

At the narrow passage there is no brother and no friend. (Arabian)

However, this brother-friend scale goes on:

A good neighbour is a good friend. (Mexican)

A good neighbour is better than a brother far off. (Danish)

A friend to my table and wine, is no good neighbour. (French)

A possible relation between lover and friend may be expressed as in

The same man cannot be both friend and flatterer. (Poor Richard)

Absence, and a friendly neighbor, washeth away love (English)

Note: Poor Richard is a pseudonym of the famous American diplomat, politician and inventor Benjamin Franklin who have collected and published many proverbs in his Almanach.

\subsection{Friend and Friends}

\section{Need of Friends}

Every man or woman must, next to one's family, have some friends, usually, since friendship is necessary in life:

Friends are flowers in the garden of life. (Portuguese)

There is no need like the lack of a friend. (Irish) 


\section{Support and Help}

A complex proverb suggests main types of support in difficult or painful situation, advising us:

Go to friends for advice; to women for pity; to strangers for charity; to relatives for nothing. (Spanish)

Perhaps the commonest idea of friend is expressed by someone ready to help one in any way, $\mathrm{cf}$

A friend is known in time of need. (French)

A friend is proven in time of necessity. (Roman)

Friends are known in time of need. (Dutch)

Friends are proved by adversity. (Roman)

Friends are known in times of danger. (Irish)

A friend is not known till he is lost. (Italian)

To stress this feature of help and assistance, often a stronger name is used, namely good friend:

A good neighbor is a good friend. (Mexican)

A good friend is better than silver and gold. (Dutch)

A friend's frown is better than a fool's smile. (Danish)

\section{Availability, Consolation and Advice}

In this sense, friend is a safeguard in crisis being invaluable, ready to help, available, when needed, and also as a source of consolation and advice

A friend at one's back is a safe bridge. (Dutch)

A friend is better than money in the purse. (Dutch)

A friend is the solace of life. (Roman)

On the road between the homes of friends, grass does not grow. (Norwegian)

A mile walk with a friend has only one hundred steps. (Russian)

The road to a friend's house is never long. (Danish)

Only your real friends will tell you when your face is dirty. (Burmese)

A friend by thee is better than a brother far off. (Irish)

To lose $a$ friend is the greatest of all losses. (Roman) 
Most friends one relies on are old friends since there is a joint experience and time enjoyed together, $\mathrm{cf}$.

A man's oldest friend is his best. (Roman)

Old age comes with friends. (Albanian)

Old friends and old wine are best. (German)

\section{True Friend and Companion}

A very special case in one's life is true friend, since no-one has too many of these. They are those one trusts. True friends are since no-one companions in one's life:

A true friend is a rare bird. (Roman)

A true friend is a second self. (Roman)

A true friend is certain when certainty is uncertain. (Roman)

A true friend laughs at your stories even when they're not so good, and sympathizes with your troubles even when they're not so bad. (Irish)

True friends are tested in adversity. (Roman)

The name of friend is common, but a faithful friend is rare. (Roman)

\section{Friend and Myself/Oneself}

Friends help one to understand himself or herself better offering kind and helpful criticism and suggesting a picture of oneself:

A friend is one soul in two bodies. (Roman)

A friend's eye is a good mirror. (Irish)

If you have a good friend, you don't need a mirror. (German)

Tell me who's your friend and I'll tell you who you are. (Russian)

When the character of a man is not clear to you, look at his friends. (Japanese)

\section{Friends Are not Ideal}

No-one is perfect, therefore one should not unduly idealize one's friends, be aware of his/her qualities and only then safely rely on them, such as in

A friend is to be taken with his faults. (Portuguese)

A friend's faults may be noticed, but not blamed. (Danish)

Unless you bear with the faults of a friend, you betray your own. (Roman)

Looking too closely at the affairs of a friend spoils the friendship. (Yoruban)

Silence is wisdom and gets a man friends. (Roman) 
Old friends and old ways ought not to be disdained. (Danish)

Once a friend, always a friend. (Kurdish)

However, friends may be demanding and even dangereous and hence, worse than an enemy, as in

Save us from our friends (Italian)

The idea is an old one, found, eg. in OVID Ars Amatoria I. 751, AD 2

Non est hostis metuendus amanti. Quos credis fidos effuge: tutus eris, an enemy is not to be feared by the lover.

Shun those whom you believe friends; then you will be safe.

Yet, to switch to a lighter side of this solemn and grave aspect, a quite different and, in fact, a humorous proverb may be added, $\mathrm{cf}$.

One may live without one's friends, but not without one's pipe. (Irish)

\section{Making Friends}

Ways to meet and make friends are many, some highly personal, professional or social. Thus, many different types of friends are made and one's behaviour is adapted or restricted to this. In many cases, it is property and riches that influence the status of friends, cf.:

Make a friend when you don't need one. (Jamaican)

Have but few friends though many acquaintances. (Danish)

Over the bottle many a friend is found. (Yiddish)

A friend that you buy with presents, will be bought from you. (Roman)

Make new friends, but don't forget the old ones. (Yiddish)

It is as bad to have too many friends as no friends at all. (Roman)

He who makes friends of all keeps none. (German)

People of the same stock and trade are friendly. (Irish)

Spend a new penny on an old friend and share an old pleasure with a new friend. (Chinese)

You can hardly make a friend in a year, but you can easily offend one in an hour. (Chinese)

Friendship, however, may be opportunistic and selfish

Prosperity is never friendless. (Greek)

Success has many friends. (Greek) 
In prosperity you may count on many friends; if the sky becomes overcast you will be alone. (Roman)

In happy times we reckon many friends; but if fortune fails, we will have no friends. (Roman)

\section{Spending Time and Life with Friends}

Living with friends may be both pleasurable and sincere, but also demanding time and energy. However, the extent of this relation should not be overtaxed, $\mathrm{cf}$.

Friends and wine: the older the better. (Spanish)

Friends are like fiddle strings: they must not be screwed too tight. (Italian)

Friends are sometimes troublesome. (Roman)

Friends are thieves of time. (English)

Many friends will sit at the same table. (German)

One must be wary while meeting friends, especially those who take different views, cf.

A thousand cups of wine do not suffice when true friends meet, but half a sentence is too much when there is no meeting of minds. (Chinese)

\section{Relations between Friends}

True friends expect you to do the same for them what they would do for you. Real friends are tested over time and actions. Yet, some caution, even sacrifice and a lot of consideration is necessary when a friend is concerned, $\mathrm{cf}$.

Mind neither storms nor snows for the sake of a friend. (Georgian)

He is my friend that grinds at my mill. (Danish)

He is my friend that succors me, not he that pities me. (Danish)

Keep your mouth, and keep your friend. (Danish)

Speak well of your friend; of your enemy, neither well nor ill. (Italian)

Keep your friends close, your enemies closer. (American)

Tell your friend a lie; if he keeps it secret, tell him the truth. (Spanish)

Friends are to be regarded from deeds, not words. (Roman)

A small house will hold a hundred friends. (German)

A stone from the hand of a friend is an apple. (Moroccan)

When interests of two friends clash, it is better to be prudent in such a dangerous situation, $\mathrm{cf}$.

He who judges between two friends loses one of them. (French) 
If a minor clash is imminent, it should be quickly removed, amicably.

Win a bet of your friend, and drink it on the spot. (Portuguese)

\section{Mutual Dealings}

A possible pitfall in one's relation with friends is property and money, $\mathrm{cf}$.

If you lend money to a friend, you lose both money and a friend. (Korean)

He that lends loses a friend. (German)

Your friend lends and your enemy asks payment. (Dutch)

Trade knows neither friends nor kindred. (French)

The Devil is a great friend of the wealthy. (Spanish)

Promises may make friends, but performance keeps them. (German)

Just a note to lending-money proverb: it is not clear why the author chose to attribute it to Korea. The proverb is very common elsewhere, made immortal by Shakespeare in 1600-1 in Hamlet (I, iii), cf.

Neither a borrower nor a lender be; For loan oft loses both itself and friend.

\section{Losing a Friend}

Although friends are a life-long achievement, they may, by natural causes, be parted, $c f$.

He that ends a friendship was never a good friend. (German)

Poverty parts friends. (Portuguese)

Long absence changes friends. (French)

The best of friends must part. (English)

When death takes your friends, it is a warning to yourself. (Yoruban)

\subsection{Friendship: The State, Process and Actions}

Some aspects of friendship suggest friendship's substance, quality and how to maintain it.

\section{Substance of Friendship}

Friendships know no age. (Spanish)

Friendships should be immortal, enmities should be mortal. (Roman) 
True friendship is seen through the heart, not through the eyes. (American)

Friendship always benefits; love sometimes injures. (Roman)

Shared friendship is a double friendship. (German)

Gold is proved in the fire, friendship in need. (Danish)

To give counsel, as well as take it, is a feature of true friendship. (Roman)

There is no better friend in winter than a warm cloak. (Spanish)

Of clothing, the newer the better; of friendships, the older the better. (Chinese)

\section{Quality of Friendship}

He who sows courtesy reaps friendship, and he who plants kindness gathers love. (Spanish)

Suspicion is the poison of friendship. (French)

Hatred watches while friendship sleeps. (French)

The friendship of a great man is like the shadow of a bush, soon gone. (French)

The friendship of officials is as thin as paper. (Chinese)

The friendship of the great is fraternity with lions. (Italian)

\section{Maintaining Friendship}

In forming new friendships, forget not old friends. (Roman)

Little presents maintain friendship. (French)

Short visits make long friendships. (English)

To preserve friendship one must build walls. (Italian)

The one who sows charity reaps friendship and he who plants kindness gathers love. (Spanish)

While you seek new friendships, take care to cultivate the old ones. (Roman)

\subsection{Inappropriate Friends}

Not all friends are friends in the positive, prototypical way mentioned above, $\mathrm{cf}$.

A friend to all is a friend to none. (German)

A friend to everybody is a friend to nobody. (Spanish)

The constant friend is never welcome. (Yiddish)

The false friend is like the shadow of a sundial. (French)

A false friend and a shadow attend only while the sun shines. (Poor Richard)

The tongue of a bad friend cuts more than a knife. (Spanish)

Our own kin are the worst friends, said the fox, when he saw the dogs after him. (Danish)

The courts of kings are full of men, empty of friends. (Roman)

A lazy shepherd is a wolf's friend. (Welsh)

A thief and darkness are friends. (African) 


\section{Friends and Enemies}

The usual opposite of friend, the enemy, may not be general, sometimes it is not mentioned at all, yet it exists. One can draw a lesson or two from some enemies, too, $\mathrm{cf}$.

One enemy can harm you more than a hundred friends can do you good. (German)

One enemy is too many, a hundred friends is too few. (Indian)

Speak well of your friend; of your enemy, neither well nor ill. (Italian)

A friend is got for nothing, an enemy has to be paid for. (Yiddish)

If you would keep your secret from an enemy, tell it not to a friend. (Poor Richard)

In the house of your enemy, make the wife your friend. (Spanish)

The role of enemy may become blurred and get various interpretations, $\mathrm{cf}$.

My friend's enemy is often my best friend. (German)

Wine is first a friend, then an enemy. (Unknown)

Your friend lends and your enemy asks payment.(Dutch)

A reconciled friend is a double enemy. (Spanish)

He cannot be a friend to any one who is his own enemy. (French)

The enmity of the wise is better than the friendship of fools. (Egyptian)

A courageous foe is better than a cowardly friend. (Chinese)

Sometimes, human folly and enmity may meet in a single proverb, cf.

A foolish man may be known by six things: anger without cause, speech without profit, change without progress, inquiry without object, putting trust in a stranger, and mistaking foes for friends. (Arabian)

\section{Other and Nonhuman Friends}

Obviously, friend/s are sometimes extended to mean non-humans as well. Few of those include dog, book and other, not necessarily living objects, cf.

A book is a friend. (American)

A dog is a man's best friend. (American)

A dog with a bone knows no friend. (Dutch)

He who goes to bed with dogs, will wake up with fleas. (German)

The cat is friendly, but scratches. (Spanish) 
The cock cannot profit by friendship with the fox. (Georgian)

Night has no friend. (French)

\section{A Conclusion and a Moral}

There are few aspects that are not covered by proverbs, usually. For a good reason, of course. Obviously, sex seems to avoid friendship (i.e. in proverbs, not in life, perhaps), and the same holds for politics and friendship. Referring to the latter, let us remind ourselves what Thomas Jefferson said to William Hamilton in 1880 this:

„I never considered a difference of opinion in politics, in religion, in philosophy, as cause for withdrawing from a friend."

Of course, this relationship is open to interpretation again and we shall never know whom Jefferson had taken for friend.

The proverbs selected and commented on here suggesting many aspects of friend and friendship in many languages and, probably, centuries, do not lend easily to a simple summary.

So, is there a moral to all of this, after all? Yes and no: all proverbs do offer their own specific morals, so to speak. Yet, two proverbs may deserve to be singled out in conclusion, one reaffirming the unshakeable status of proverbs in life, the other pointing to a hidden logical and philosophical link between the proverb and the truth:

A friend is the solace of life. (Roman)

Truth is better than friendship. (Indian)

\section{REFERENCES}

BraY, Alan. 2006. The Friend. Chicago, Ill.: University of Chicago Press.

CiCERo, Marcus Tullius. 1923. De amicitia. Sbírka překladů klasiků řeckých a ř́mských, 1923, Dr. J. Schubert: Praha.

ČERMÁK, František. 2013. Základní slovník českých př̌sloví. NLN: Praha (A Basic Dictionary of the Czech Proverbs).

DAVIES Mark - GARDNER, Dee. 2010. A frequency dictionary of contemporary American English: Word Sketches, Collocates and Thematic Lists (Routledge Frequency Dictionaries). London et al.: Routledge.

LePP, Ignace. 1966. The Ways of Friendship. New York: The Macmillan Company. 
Simpson, John - SPEAKe, Jennifer. 2015. Oxford Dictionary of Proverbs. $6^{\text {th }}$ edition. Oxford U. P.: Oxford.

StonE, Jon R. 2006. Routledge Dictionary of World Proverbs. London - New York: Routledge.

\section{František Čermák}

Professor emeritus of the Charles University Prague

Institute of the Czech National Corpus

Charles University, Faculty of Arts

nám. Jana Palacha 2, 11638 Praha 1

Czech Republic

frantisek.cermak@ff.cuni.cz 
